\title{
PRE-PRINT
}

\section{Balance between auditing and marketing: An explorative study}

\author{
Pernilla Broberg, Timurs Umans ${ }^{1}$, Carl Gerlofstig
}

Kristianstad University, Department of Business Administration, 29188 Kristianstad, Sweden

Accepted for publication at Journal of International Accounting, Auditing and Taxation (2013)

\footnotetext{
${ }^{1}$ Corresponding author. Tel.: + 4644203137.

E-mail addresses: pernilla.broberg@hkr.se (P.Broberg), timurs.umans@hkr.se (T.Umans), carl@gerlofstig.se (C.Gerlofstig)
} 


\begin{abstract}
Abtsract
This study explores how auditors' attitudes toward marketing and their views on the importance of marketing affect how they balance their time spent on marketing and auditing activities. The purpose is to understand how changes in the business environment for auditors affect the relationship between the auditing profession and marketing. The study is based on a survey of 711 auditors in Sweden. The findings suggest that auditors with a positive attitude toward marketing spend significantly more time on marketing activities compared to those with a less positive attitude. Furthermore, auditors who view marketing activities as important spend significantly more time on marketing activities. The study controlled for the number of years as approved or authorized auditor, age of the auditor, and firm affiliation. The results indicate that the theoretical distance between the auditing profession and marketing does not exist in practice to the same degree as it used to. The findings of the study have implications for international auditing theory and practice in illuminating the relationship of marketing and auditing in a wider business context.
\end{abstract}

Key words: Auditor, auditing, marketing, profession, professional services firm, Sweden 


\section{Introduction}

Research on auditing as a professional service and its relationship to marketing have emerged over the past decade, presumably as a response to changes in the business environment. Inquiry into the relationship has usually taken one of two directions. One stream of research has investigated changes in auditors' attitudes toward marketing (Clow, Stevens, McConkey \& Loudon, 2009; Ellingson, Hiltner, Elbert \& Gillett, 2002; Tang, Moser \& Austin, 2002), while the other stream has focused on auditors' marketing practices (e.g. Ellingson et al., 2002; Heischimdt, Elfrink \& Mays, 2002). Both streams show that increasing competition due to the large number of new auditing firms entering the market creates hypercompetition in the industry and changes the attitudes and practices of marketing by auditors as well as consequently reshaping the practice of auditing itself (Heischmidt et al., 2002). In an industry that, prior to 1977, viewed marketing as unethical and advertising as violating the professional code of ethics (Clow et al., 2009; Heischmidt et al., 2002), the increase in competitive pressures makes auditors realize the importance of marketing. This in turn leads to the realization that the profession has had to recognize the importance of pure business skills (Jönsson, 2005). Traditionally, the role of the auditor was to ensure the quality of the accounting information (Öhman, 2005; Power, 1999), which implied a review of the measurements and communications of accounting for correctness in an analytical and critical manner (Mautz \& Sharaf, 1997). A number of studies have investigated how customer relationships, customer acquisition, maintenance of the customer relationship as well as customer retention constitute parts of the audit function (Behn, Carcello \& Hermanson, 1997; Cameran, Moizer \& Pettinicchio, 2010; Öhman, Häckner \& Sörbom, 2012), usually performed by means of referrals and networks. Recent studies have also shown that auditors are committed to the client and want to add value through the auditing service (Herda and Lavelle, 2012; Broberg, forthcoming). However, others note that the role of auditors is in 
transformation (Ellingson et al., 2002; Heischmidt et al., 2002) and what used to be a relatively passive marketing function of the profession is evolving to an active participation of auditors in customer acquisition and retention (Hackenbrack \& Hogan, 2005; Hodges \& Young, 2009) by means of marketing and advertising rather than by referrals and networks all in order to differentiate services from those of competitors.

The aim of this study is to explore the attitudes of auditors toward marketing and to investigate their actual marketing practices. In doing so, this research attempts to contribute new insights to both theoretical and practical aspects of auditing. The study investigates the balance between auditing responsibilities and marketing actions. The theoretical contribution is an exploration of the relationship between the auditing profession and the marketing activities of professional services firms. As for practical implications, marketers in general and auditors in particular can gain practical knowledge of how to meet the changing environment of the profession in a balanced way through marketing activities.

Changes in the business environment of auditors and the traditional view of the distance between professional engagements and marketing might at first glance indicate that the level of professionalism becomes lowered to allow for other activities to take place. In addition to the more traditional tasks of auditors, marketing activities must be performed both to retain existing clients and to gain new clients. Also, based on the fact that auditing is a service, and marketing is an inherent function of service firms, there is a theoretical aspect of the issue as auditing is not traditionally related to marketing. The problem can be viewed as a doubleedged sword: On the one side is the auditing profession with its traditional tasks and code of conduct and on the other is marketing activities that auditors and audit firm have become more aware of and inclined to adopt to retain competitive edge. The perceived animosity 
between marketing and auditing and its influence on auditing as a profession remains an empirical question, which this paper will attempt to address.

The issue of including marketing activities in the profession is of immediate concern for auditors in Sweden. As of 2009, Sweden and Malta were the only two countries within the European Union with statutory audit. However, in November 2010, the statutory audit for all public companies was abolished in Sweden ${ }^{2}$. The abolition affected more than 250,000 public companies in Sweden, at least $70 \%$ of which have chosen to have audits. This particular situation thus serves as a golden opportunity for empirical investigation of the auditing profession in transition from an imposed to a marketed function. Auditors must now not only promote themselves and their firm but also promote why the (prospective) client needs an audit. Moreover, the transition in Swedish regulation of the statutory audit creates an opportunity to bridge the two streams of research outlined here and to explore both the attitudes of auditors toward marketing as well as the role of marketing as a part of auditing practice.

Given the internationalization of auditing (cf. e.g., Humphrey, 2001), such that the Big Four audit firms are operating cooperatively on local, national, and global levels, it could be assumed that the Swedish Big Four 4 audit firms are influenced and affected by that setting. We suggest, therefore, that the results of this study are valid across jurisdictions. While the study uses Swedish data, we suggest that investigation of the marketing and auditing relationship may have a wider international appeal. First, the paper illuminates the process of change within the auditing profession triggered by the regulatory changes (abolition of the statutory audit in Sweden), thus presenting an interesting empirical case of the contextual 
influences on the auditing profession. Second, the paper shows how specific business practices (marketing being the focus in this paper) intertwine with the traditional tasks of an auditor, thus presenting the process of change within the practice of auditing. Overall, this study addresses both theoretical and empirical problems of the relationship between marketing and auditing that could be of interest internationally.

\section{Literature review}

Auditing has been traditionally defined as a profession - along with medicine, law, and engineering, among others. The designation "professional” for these occupations has been earned since all of them constitute "exclusive groups of individuals applying somewhat abstract knowledge to particular cases” (Abbott, 1988: 318). Exclusivity of the profession in general is ensured by the possession and use of skills and theoretical knowledge, while competence is ensured by comprehensive examinations which then lead to membership of the carefully regulated institutes that act as barriers to entry (Hodges \& Young, 2009). Being part of the profession also means adherence to an enforced code of ethics and professional conduct in order to secure the quality of the service provided, especially in light of the idea that these services are being performed for the common good (Abbott, 1988; Millerson, as cited in Brante 1988). Professional services that Abbott and Millerson refer to are further distinguished by "being mainly advisory, and operated by skilled professionals" (Gummesson, 1979: 308).

While some might think that the profession and its professional services have been rather resistant to changes, due to the governing principles at the core of the profession as well as professional organizations that serve as gatekeepers at the entry into the profession, recent

\footnotetext{
${ }^{2}$ From November $1^{\text {st }}, 20120$, only companies exceeding two of the following three requirements must still be audited: total assets 1,5 MSEK (approx. \$215K), net sales 3 MSEK (approx. \$430K), and 3 employees (on
} 
research have shown otherwise. Several studies have shown that the business environment for professional services is changing (Hodges and Young, 2009; Kotler and Connor, Jr., 1977; Mautz and Sharaf, 1997; Reid, 2008). Not only does the environment force professional services firms to consider market orientation as well as to build and leverage client relationships (Reid, 2008) in order to gain competitive advantage (Hodges and Young, 2009), but also it requires a continuing modification of the relationships to these clients and other stakeholders in the environment (Mautz and Sharaf, 1997). While Kotler and Connor, Jr. (1977) observe that in order to adapt to the market-oriented environment and its everchanging nature, professional services firms have to be able to manage codes of ethics, changing expectations of clients, and increasing competition and attitudinal barriers such as commercial disrespect and association of marketing with selling, these firms have had a hard time adopting such principles - in particular, their view of marketing (as "selling”) and its role within the profession (Reid, 2008). The association of marketing with selling is explained by the idea in professional circles that the use of salespeople is not suitable in professional services firms as buyers want to meet and get acquainted with the professionals actually providing the services (Kotler et al., as cited in Hodges \& Young, 2009).

This study focuses on auditors as providers of professional services. While such services traditionally have been associated with certain tasks, responsibilities, and professional conduct, they have been rather unassociated with marketing tasks. To study how auditors balance their inherent auditing responsibilities and conduct with the imposed marketing tasks, it is important to know what tasks are included in the auditing profession and what characterizes the marketing of professional services. Included in this review of relevant issues is a discussion about previous research in the marketing of professional services in general 
and the auditing profession in particular. As previous research originates from both American and European traditions, the terms “accounting/accountant” and "auditing/auditor" are used interchangeably. The meaning of the words is the same, but for consistency the terms “auditing” and "auditor” are used, with the exception of verbatim quotations.

According to institutional theory, professional services firms are subject to normative pressures. These pressures arise from the formal education of specialists and the networks spanning across firms, and they force professional services firms to make structural changes (DiMaggio \& Powell, 1983). The structural changes form the professional bureaucracy in which the operating core - the professional - is emphasized through the coordination of their standardized skills (Mintzberg, 1983). Also, the structure of a professional services firm, operated by skilled professionals, is typically associated with distinct career patterns that most often reflect status and formal authority (Abbott, 1988; Gummesson, 1979; Mintzberg, 1983). The distinct career patterns in a professional services firm are driven by "status competition” and are closely guarded, both at entry and continuously throughout the career path, such that individuals with the highest rank are "virtually indistinguishable [from one another]" (DiMaggio \& Powell, 1983: 153-154).

The services offered by professions are highly complex, customized, and delivered by highly qualified personnel. Even though the studies presented above date back some decades, they are still relevant and applicable to professional services firms. As the business environment has changed, with increased competition and more technically "savvy" clients, process and outcome quality have become more important factors in relationships with clients (Reid, 2008). Furthermore, it is difficult to achieve differentiation in professional services offerings, which is challenging for the firms (Hodges \& Young, 2009). The pluralistic framework of 
marketing adopted by most professional services firms involves both transactional engagements and closely managed relationships with clients (Reid, 2008). The relationships both within the professional services firm and with the external clients are critical to achieving competitive advantage (Hodges \& Young, 2009). Thus, relationship marketing becomes critical to establishing the perception of clients that the service offered by a particular auditor is different from that of another. Although relationship marketing is not the primary focus of this study, it is an important factor of the complex issue and should not be excluded from the discussion.

Previous research shows that even though few professional services firms organize for marketing activities, there is evidence that they follow some of the most sophisticated marketing principles (Hodges \& Young, 2009). The research have also shown that marketing activities are being performed not only by those assigned to the marketing department, but is a function that involves all levels of the organization” (Gummesson, 1979) and is integrated with organizations' operational activities (Ashill, Davies \& Thompson, 2003). The professional acts as a part-time marketer, guided by the marketing department and the financial goals set by the firm, and has to act and think in a marketing-oriented manner (Grönroos, 2007). As part-time marketers, the activities of professionals include marketing functions to retain existing customers and gain new ones. Although most of the marketing in professional services firms is not done by marketing specialists, it is highly advanced and effective (Hodges \& Young, 2009).

Auditing is a widely known professional service (Reid, 2008; Van Doren, Smith \& Biglin, 1985). The functions of auditing arise from the demand by various stakeholders of a firm that the financial information released in the firm's reports be reliable. Thus, the role of the 
auditor is to ensure the quality of the accounting information (Öhman, 2005; Power, 1999). Power (1999) concludes some general concepts of the auditing practice: “independence from the matter being audited; technical work in the form of evidence gathering and the examination of documentation; the expression of a view based on this evidence; a clearly defined object of the audit process” (Power, 1999:5). The auditor must stay within certain frameworks that follow from the legal responsibility of the auditing profession. However, the auditor must consider not only the many regulations that control the work but also several codes of conduct and code of ethics such as the generally accepted auditing standards (GAAS) and professional ethics for accountants when delivering the service to clients (Öhman, 2005).

To provide trust and confidence the auditor need to be perceived as experienced. This however can be seen as complicate task, since services such as auditing are complex and therefore hard for clients to assess (O’Donohoe, Diamantopoulos \& Petersen, 1991). However irrespective of the complexity it is the auditors that know their trade best and thus are expected to sell it in the best possible manner, which in turn being reinforced by financial goals set by the board of directors of audit firms. This in turn puts pressure on the individual professional to increase the volume and profit of the business. Consequently auditors need to include various marketing activities in the relationships with clients. In the modern auditing firm, this means more than just attending business lunches and holding country club memberships (Hulbert \& Lawson, 1996). Client and prospective client seminars and other public relations activities were among the most important marketing tactics in a recent study of accountants (Markham, Cangelosi \& Carson, 2005). For smaller firms, this is a bigger problem as they normally have fewer resources to allow for such marketing activities. At the same time as auditors perform marketing activities, they have to follow the codes of conduct 
and other standards set by the regulating institutions. Moser, Colvard and Austin (2000:17) conclude their study of consumers' attitudes toward advertising by auditors by stating that "accountants who can find the balance that consumers perceive is necessary in terms of reputation, credibility, image, and the information function will likely be successful in their advertising efforts.” Therefore, it is important for the auditor to carefully balance the time spent on the imposed marketing activities and the inherent tasks of the auditing profession to make sure that the trust and confidence in the profession are not damaged.

The regulations and codes of conduct for auditors suggest that even though other professional services firms involve the marketing function, auditors have not been able to imply such changes in their profession. The shift in auditors' attitudes toward marketing began after a U.S. court decision in $1977^{3}$ and has evolved further since then. Several studies have focused on auditors' attitudes toward marketing (Clow et al., 2009; Ellingson et al., 2002; Tang et al., 2002). A longitudinal study by Clow et al. (2009) compared auditors' attitudes toward marketing in 1993 with attitudes in 2004. The results indicated that the auditors' negative impression of marketing changed to a much more positive attitude; this change in auditors' attitudes toward marketing was further strengthened by the increased use of marketing activities as auditors established and retained relationships with clients (Clow et al., 2009). In particular, younger auditors entering the auditing profession use various marketing activities to promote their images and services. They use advertisements, sponsorships, seminars, and electronic media (such as websites) to promote and increase the awareness of their names (Clow et al., 2009; Hulbert \& Lawson, 1996). While Clow et al. (2009) provided the framework for study of auditors' perceptions of advertising (as one specific technique of marketing), the questions posed in their study put a major emphasis on the change of attitudes 
rather than on what are the outcomes of the change. Our study thus tries to differentiate and at the same type develop the ideas of that work by exploring the outcomes of the attitudinal change, as well as further distinguishing the attitudes and perceived importance of marketing. Instead of looking at the attitude toward one specific marketing technique (advertising in Clow et al., 2009), our emphasis is on marketing as a set of various tools and techniques. From this discussion, it is worthwhile to further explore auditors' attitudes toward marketing. Included in the role of auditor are the various tasks of working with clients on a continuous basis. Consulting and guidance are two examples of such tasks. Since the statutory audit was abolished in Sweden, it has become more important for the auditor to convince clients that auditing is necessary for them. It is also important to convince clients that the additional nonaudit consulting services can be of value to them (Johansson, Häckner \& Wallerstedt, 2005). However, adding to the complex nature of the problem is the Swedish law limiting the consulting possibilities between auditors and clients. The issue can be viewed as the relationship between the auditing culture, based on facts, and the consulting culture, based on possibilities (Jönsson, 2005).

Some studies have investigated the adoption of marketing activities by auditors (e.g., Diamantopoulus, O’Donohoe \& Lane ,1899; Ellingson et al., 2002; Heischimdt et al., 2002). This research indicates that young auditors believe that a good professional image can be established and maintained with appropriate use of marketing. The finding suggests that young auditors see advertising as an important marketing strategy that can help them expand their client base (Hulbert \& Lawson, 1996). Thus, it is suggested that auditors who view marketing as an important part of the work also balance the marketing and the inherent tasks of the auditing profession.

\footnotetext{
${ }^{3}$ In 1977 the Supreme Courte ruled in the Bates v. State Bar Arizona (1977, 97S. Ct. 2691, 34 U.S., L.W. 4895) case that professional organization can no longer prohibit their members to perform advertising, and that the
} 
In this literature review, we have pointed out several issues related to the balance between marketing and auditing. To investigate these issues further, by means of an explorative questionnaire, we aim to address the research question: "How do auditors balance auditing and marketing activities?”.

\section{Method}

This section describes the research method. It starts with a discussion of the sample selection process and descriptive statistics for the sample. This is followed by a presentation and discussion of the survey; we describe how the variables have been operationalized. In the following section, the results from the statistical analyses are presented and the findings discussed.

The initial sample consisted of all authorized and approved auditor members of FAR SRS, the professional institute for accountants and auditors in Sweden. The total number of registered member e-mail addresses in May 2010 was 3,556 (FAR SRS search result, 2010). These addresses were collected and an electronic survey was distributed to all of the 3,556 auditors in the initial sample. A questionnaire was chosen for this study; it is an efficient method of collecting data from large samples and has been used by researchers in previous studies (e.g., Clow et al., 2009; Ellingson et al., 2002; Heischimdt et al., 2002; Markham et al., 2005; Tang et al., 2002); moreover, although the approach of this study is explorative in nature, we intend to uncover the relationships and patterns that quantitative methods could help to shed light on. An exploratory interview was conducted with an authorized auditor prior to the distribution of the questionnaire in order to check whether our questions were understood in the way we 
intended. This resulted in the rephrasing of some questions; also, a few background questions were removed from the original questionnaire.

From the initial sample, a total of 711 respondents submitted their answers (a response rate of 20\%). Five respondents (0.7\%) did not answer the question on gender, eighteen respondents (2.5\%) did not answer the age question, 25 respondents (3.5\%) did not answer the question on how many years as approved or authorized and two (0.3\%) respondents did not answer the question on firm employment. The final sample consisted of 672 responses. Of the 672 respondents there were 222 females (33\%) and 450 males (67\%). The average age of the respondents was 46.76, ranging from 26 to 78 years, and the average number of approved or authorized auditor was 14.51 with a minimum of 0 and a maximum of 44 years. 33 (4.9\%) respondents replied that they work for BDO, 28 (4.2\%) for Deloitte, 85 (12.6\%) for Ernst \& Young, 30 (4.5\%) for Grant Thornton, 85 (12.6\%) for KPMG, 147 (21.9\%) for PricewaterhouseCoopers, 16 (2.4\%) for SET, and 248 (36.9\%) responded that they work for other, not specified, firms.

\subsection{Operationalization}

All items in the questionnaire were in Swedish to avoid misinterpretations, an issue that would otherwise decrease the measurement validity of the results. The questionnaire was divided into four parts. The first part included four background (demographic) questions: gender, age, number of years as authorized or approved public auditor, and which firm the auditor belonged to. These items were all used as control variables. Gender was measured as male or female and used as a dummy variable in the analysis. Age (of the auditor) and number of years as approved or authorized auditor were measured on a continuous scale. The fourth control variable, firm, was measured as a dummy variable with seven predetermined firms 
(BDO, Deloitte, Ernst \& Young, Grant Thornton, KPMG, PricewaterhouseCoopers, and SET) and one option (“Other”) for firms other than these seven.

The rest of the questionnaire was divided into three subparts, where we asked the auditors about the perceived importance, attitude, and time spent on marketing and auditing activities. The respondents were asked to mark their opinion on a 7-point Likert scale ranging from "Strongly disagree" (1) to "Strongly agree" (7) for each of the 12 activities listed in Table 1, which were derived from previous literature as well as the explorative interview.

-Table 1 comes about here

In order to answer our research question, "How do auditors balance auditing and marketing activities?” - auditor's attitude toward marketing and auditor's view on the importance of marketing were defined as independent variables while perceived balance between marketing activities and the inherent tasks of auditing was assigned as the dependent variable. In sections 3.2 and 3.2, we describe how the independent and dependent variables were constructed.

\subsection{Independent variables}

Auditor's attitude toward marketing, used as an independent variable, was operationalized as an index of the average scores ${ }^{4}$ for all the marketing activities. The scores were added for each of the respondents, and the sum was divided by the total number of activities. The variable was labeled “Attitude M.”

\footnotetext{
${ }^{4}$ According to Hair, Black, Babin \& Anderson (2010), a summated scale has the advantage of reduced measurement error; it represents the multiple facets of a concept and may be used as a compromise between the use of a surrogate variable and the use of factor scores. The use of summated scores, however, requires that reliability tests are performed.
} 
Auditor's view on the importance of marketing, used as an independent variable, was operationalized as an index of the average scores for all the marketing activities. The scores for the activities were added for each of the respondents, and the sum was divided by the total number of activities. The variable was labelled "Importance M" 5 .

\subsection{Dependent variables}

Perceived balance between marketing activities and the inherent tasks of auditing, used as a dependent variable, was operationalized as the difference in time spent between marketing activities (“Time M”) and auditing activities (“Time A”) The average score was calculated by adding the scores for the activities for each of the respondents, and the sums were divided by the total number of activities. The variable "Balance Time” was created by subtracting the average scores for all auditing activities from the average scores for all marketing activities.

\subsection{Other variables}

Given the explorative nature of our paper, we also explored respondents' attitude toward auditing activities (“Attitude A") and perceived importance of auditing activities ("Importance A"). While these variables were not included in the regression analysis because the primary focus was on attitude to and importance of marketing activities, in terms of their influences on balance of time spent on the two activities, we chose to include them in the correlation matrix in order to explore how these variables correlated with the others. Moreover Attitude A and Importance A are used in the discussion and explorative factor analysis (PCA) presented in the later sections of this paper.

\footnotetext{
${ }^{5}$ The analysis was also performed using regression factor scores, but the results were no different from those using the summated scales.
} 


\section{Empirical findings}

Cronbach’s alpha was calculated for Attitude M, Importance M, and Time M; all have values above 0.7 and are considered to be within acceptable limits (Pallant, 2007). However, the value of 0.676 for Time A is slightly below the preferred value of 0.7 . This was considered when further tests were performed on the data. We have also performed confirmatory factor analysis (principal axis factor analysis with direct oblimin Kaiser normalization) which has verified the factor structure derived in above mentioned tests.

Pearson's correlation was used as an indicator of the strength and direction of the relationships. The results are shown in the correlation matrix (Table 2). Relationships were investigated further through regression analysis. To test the robustness and increase the validity of the data and the results, the data were randomly divided into three groups. The number of respondents was 224 in each of the three groups we have divided the sample into. The groups were individually tested with regression analysis; no significant differences were found between the three groups and the undivided sample. Due to space limitations, only the results from the regression analysis performed on the undivided sample are presented in this article (Tables 3 and 4). Five regression models are presented here; the number of the models is due to multicollinearity between different variables ${ }^{6}$.

\footnotetext{
${ }^{6}$ Multicollinearity was indicated when all control variables were included in the regression. Also, indications of multicollinearity were found when excluding age or years as auditor and including all of the recoded control variables for the firms. No indications of mutilcollinearity were found for any of the remaining multiple regression tests. Therefore, five regression models were used to further test the relationships suggested by the correlation coefficients. Due to the indications of multicollinearity, the control variables age and years as auditor were separated in all models. Also, the control variable firm was excluded from three of the models. The dummies of the firm variables were highly correlated with age and years as auditors when in the same
} 
As for how auditor's attitude toward marketing influences the balance between marketing and auditing activities, it can be observed (Table 3) that each of the five models is statistically significant at the .001 level. From the standardized beta coefficients in the models, one can observe that, for all five models, Attitude $\mathrm{M}$ contributes the most in explaining the dependent variable balance between marketing and auditing activities.

We further explored how auditor's perception of importance of marketing influences the balance between marketing and auditing activities. As in the previous explorative analysis, each of the five models is statistically significant at the .001 level (Table 4). Standardized beta coefficients values in all five models are highest for Importance $\mathrm{M}$, thus indicating it as the independent variable that explains most of the variance in the dependent variable.

To find further answers to our research question, we applied principal component analysis (PCA) to the indexes - Attitude M (attitude toward marketing), Importance M (importance of marketing), Attitude A (attitude toward auditing) and Importance A (importance of auditing) as well as Time $\mathrm{A}$ and Time $\mathrm{M}$ (the two variables used to construct the variable balance time). The results are summarized in Tables 5, 6, and 7. This section presents a brief summary and discussion of the results from the explorative PCA. This analysis was performed to explore how auditors perceive the division between marketing and auditing and its practice in their day-to-day activities.

regression. Specifically, Deloitte and Ernst \& Young were negatively, while Others positively, correlated with age and years as auditor. Model 1 excluded the control variable years as auditor and firm, and Model 2 
Prior to conducting the tests, we checked our data for PCA appropriateness. We checked correlations between the variables (which exceeded 0.3), sampling adequacy (MSA, which was high), and Kaiser-Meyer-Olkin (KMO, above 0.7). Moreover, the eigenvalues and screen plot indicated that three components should be used. We also checked for communality values, with preferred value above 0.4 .

For attitude toward auditing and marketing, one communality value was 0.349 (“interact with clients online”). A separate analysis was conducted with this variable excluded, but the test did not improve the results. Therefore, all variables were included.

In the rotated pattern matrix (Table 5), we present the three components resulting from the PCA. The components are labeled according to the variables included in each component. The first component is "Marketing," the second “Auditing,” and the third “Other.” The results of the analysis show that two activities change places: "firm activities," initially assigned to auditing, loads into the marketing component, while "interact online with clients," initially assigned to marketing activities, loads into the auditing component. Moreover, “administration,” initially assigned to auditing now loads into a component of its own. One explanation for the "firm activities" loading into marketing rather than into auditing could be in some comments received on this matter from the respondents, which claimed that firm activities are strongly associated with talking to students and responding to marketing research. The variable "explain auditing is important” loads almost equally into marketing (.384) and auditing (0.332) components; in the table, we show it as included in the marketing component since we find that there is a stronger theoretical relation to marketing than to excluded the control variables age and firm. Model 3 excluded years as auditor, and Model 4 excluded age. Model 5 excluded all control variables. 
auditing. The auditing component includes four variables that originally were defined as auditing activities. The fifth variable in the component is "interact with clients online" which was considered a marketing activity. However, the interpretation of the activity might have been different from the original intention. Auditors spend considerable amounts of time interacting with clients by e-mail and interactive software. Thus, it could be reasonable to argue that this activity is related to the auditing rather than marketing activities. The third component, Other, only includes one variable, "administration." One explanation for this result is that auditors might not relate this activity to either marketing or auditing. Instead, they regard tasks such as reporting time spent on clients and invoicing clients as administration.

Table 5 comes about here

From the principal component analysis of the variable Importance of Auditing and Marketing, three components emerged, with communality values above the preferred 0.4 level (Table 6). As in the PCA for attitude, “firm-activities" were loaded into the marketing component, given the supposition that is an auditing activity. However in this PCA, "administration" and "interact online with the clients," initially assigned as auditing and marketing activities respectively, were now loaded into a third component, Other. While the reasons for including “administration” in the component Other are as previously mentioned, the fact that "Interact online with clients" is included in the component Other is somewhat surprising. Considering the different focus of Importance compared with Attitude, one can argue that the tasks performed when interacting with clients online are an important part of the auditor's work; however, auditors do not consider it either a marketing or auditing activity. 
Similarly, we performed PCA on the variable Balance Time (Table 7). An initial analysis of e Balance Time indicates that three components should be used. However, the resulting number of variables in the second component, Auditing, were not considered sufficient. Therefore, PCA with two forced factors was tested. The results of the communality values from the forced factor analysis indicated that both variables "administration" and "interact online with clients” should be removed from the test (values below 0.4). Also, the same two variables were excluded from the Marketing and Auditing components in the PCA tests above. Thus, the final PCA test included ten of the variables (activities). Again, “firm activities” initially assigned as an auditing task was loaded into the marketing activity.

-Table 7 comes about here

We performed regression tests with the components that were derived from PCA. Similar results for all the five models were attained, compared to the regression analysis performed with the initially defined constructs. The primary finding of the regression analysis is that positive attitudes towards marketing activities and increasing degree of importance attributed to marketing activities have a positive effect on the balance of time spent by auditors on auditing and marketing activities they perform. In the next section we elaborate and discuss these and other findings of afore mentioned analyses.

\section{Discussion}

The research question posed in this paper was "How do auditors balance auditing and marketing activities? To answer this rather broad question, we explored how the perceived 
importance and attitudes of auditors toward marketing influence the distribution of their time between auditing and marketing. Based on the auditor's perception of importance and attitudes toward auditing and marketing as well as our observation of the time spent on these two tasks, we used PCA to explore what they considered as auditing and marketing activities as well as how they distributed time between the two types of activity.

The results of our study indicate that auditors, on average, attribute rather high importance to marketing tasks as well as having a positive attitude toward these tasks. The results also show that increasing attribution of importance and positive attitude toward marketing leads to a balanced time distribution between marketing and auditing. Further analysis based on the PCA shows how auditors, through the prism of importance, attitudes, and time spent perceive the subdivision of their tasks into auditing and marketing practices. Our findings mostly support literature-derived ideas of what constitutes marketing and auditing tasks in auditing profession, albeit with some deviations. For example, firm activities, while initially considered to be part of auditing tasks are perceived as marketing, while interaction online with clients, initially attributed to marketing, is perceived as either marketing or administration. Moreover, administration, initially attributed to auditing emerges as a standalone task that belongs neither to auditing nor to marketing.

The major contributions of this paper, which differentiates this paper from previous studies, lay in (1) identification and exploration of a range of marketing and auditing activities, (2) exploration of the distinction between attitudes and perceived importance of auditors towards marketing, (3) exploration of the outcome of the attitudes and importance of auditors towards marketing in terms of perceived time balance between auditing and marketing activities of 
auditors. In sum the contributions of the paper are thus both theoretical and methodological, and as will be argued further of practical relevance.

In the next two sections (5.1 and 5.2) we comment further on the findings related to attitude and importance of marketing, respectively, and on their relationship to the time balance between auditing and marketing activities.

\subsection{Attitude}

The empirical findings of this study indicate that the auditor's positive attitude toward marketing is positively related to the perceived balance in time between marketing and auditing activities. As the auditor's positive attitude toward marketing increases, time spent on marketing increases too. The results obtained for auditor's attitude toward marketing are consistent with the findings of previous studies on the same topic (Clow et al., 2009; Ellingson et al., 2002; Tang et al., 2002). Even though the average age of the respondents (46.76) and the average number of years the respondents have been auditors (14.51) are high, the averages are relatively low compared with other studies. This may give some support to the statement that younger auditors have a more positive attitude toward marketing. The auditing activities have higher means (see Table 8) compared with the marketing activities, a result that was to some extent expected.

------------Table 8 comes about here

However, all of the marketing activities except "learn about marketing” have relatively high means. This result is very interesting, especially when related to the discussion on the traditional view of the relationship between marketing and auditing. In theory, auditing is a 
service, with marketing as an important function. However, in practice, auditors have for a long time regarded marketing as unethical and not part of their work. As one respondent in this study commented, “How can you relate auditing to marketing?” Clearly, there still exist negative attitudes toward marketing. On the other hand, the results of this study indicate that these negative attitudes are changing. Today, auditors in general have a more positive attitude toward marketing. This suggests that as auditors' attitudes toward marketing follow changes in the business environment, the practice of auditing may involve more marketing activities.

\subsection{Importance}

It was also found that auditors who find marketing activities important balance the time spent on marketing and auditing activities. In other words, when auditors' views on the importance of marketing activities are more positive, time spent on marketing activities increases. The distinction between attitudes and importance (especially towards marketing) is rare in the auditing literature. Addressing this gap, we develop the concept of perceived marketing importance, explore it through the auditing and marketing activities, and test its relationship to the perceived balance of time between marketing and auditing activities.

Marketing activities received relatively high average scores on the importance of each activity, except for the activity "learn about marketing" (mean value 3.44 in Table 8). Compared with the mean values for the other marketing activities, this finding suggests that marketing activities are practiced, but auditors do not learn about those activities.

The findings from this study support what previous researchers observed (albeit in relation to advertising, being one of the marketing activities): marketing is an important strategy to expand the business (Hulbert \& Lawson, 1996). The results of this study also support the 
statement that auditors no longer rely solely on referrals and networks. They have realized the importance of performing additional marketing tasks to gain and retain client relationships (Hodges \& Young, 2009). Since the statutory audit has been abolished in Sweden as of 2010, it has become more important for auditors to convince clients that auditing services will add value to their business. The average score for the activity "explain auditing is important" (5.16) suggests that auditors already consider this an important item. The average score for the activity "attend seminars" (5.37) suggests that auditors find it important to meet both existing and prospective clients. This result supports the findings from the study by Markham et al. (2005) that client seminars and other public relations activities were among the most important marketing tactics. In sum findings of this study confirm the results of previous studies on the importance of marketing for auditors/auditing firms. What however makes our findings different is that they provide a holistic view on marketing activities in auditing firms, while previous studies have chosen to concentrate on the isolated attributes of marketing activities. In investigating the holistic view this paper thus not only explores the variety of marketing activities in auditing firms, but also theoretically motivates and empirically established the relationship between these components and perceived balance of time spent by auditors on the auditing and marketing activities.

\section{Conclusions}

Given the traditional view on the distance between professional auditing engagements and marketing, changes in the business environment of auditors suggest that the interests of professionalism have had to make room for other activities such as marketing. Following the abolition of the statutory audit as of 2010, this issue has become even more important for auditors in Sweden. The results of this study show that auditors in Sweden have successfully adjusted to the new market conditions and have a positive attitude toward marketing activities 
as well as realizing the importance of marketing as a part of their professional responsibility. Our study also provides some indications that auditors with a positive attitude toward marketing, as well as those who view marketing as important, are to some extent able to balance the time spent on the inherent tasks of the profession with the newly imposed marketing activities. As younger auditors replace older ones, it may be assumed that toward marketing will change even further and be reflected in the work of the auditor. The conflict between auditing as a professional service and marketing is no longer as evident as it once was. Our findings imply that auditors do balance their inherent auditing responsibilities with the newly imposed marketing activities.

Future studies could investigate further the issues raised in this article and follow the development of an auditing profession that now is obliged to embrace marketing as an integral part of its services. Moreover, previous research has indicated that perception of different activities within the auditing profession depends on the age of the auditor, so it could also be interesting to investigate how the attitudes of auditors in Sweden shift, based on their demographic characteristics and the influence of changes in the environment (such as the abolition of the statutory audit). The dimension of customer acquisition could be another area of investigation within the auditing profession and might shed light on the view and practice of auditors in sales and sales development - another area that previously seemed to be far removed from the auditing function, but that will become a reality for auditors in competition with each other. Further, it would be important to investigate how attitudinal shift towards marketing in auditing profession could influence audit quality, since the latter is considered to be a desirable outcome of the auditing process. 
This study has several practical implications. Firstly, it may be used by auditors as an assurance that not only are they involved in "something” that is called marketing, since the majority of their colleagues are doing marketing, are actually finding it to be of importance, and are actually positively disposed toward it. Secondly, the study indicates that marketing is a tool to be used to respond to the increasing competition in the sector due to its maturity as well as minimization of the customer base - which Swedish auditing firms are accustomed to. Thirdly, this study may be seen by marketing professionals as a signal that the doors of once closed professions are opening up for them, and that there might be an opportunity for mutually beneficial collaboration.

Since it addresses both theoretical and empirical problems of the relationship between marketing and auditing, this study may have a wider international appeal as it illuminates the process of change within the auditing profession, triggered by the regulatory changes as well as by the inclusion of more non-traditional tasks such as marketing.

\section{Acknowledgments}

We would like to thank two anonymous reviewers and the editors for the guidance in developing this paper. David Harrison at Proper English AB has contributed with language editing. 


\section{References}

Abbott, A. (1988). The System of Professions: An Essay on the Division of Expert Labor. Chicago: The University of Chicago Press.

Ashill, N. J., Davies, K. M., \& Thompson, I. W. (2003). Characteristics of marketing organization in the New Zealand financial services sector, International Journal of Bank Marketing, 21(2), 80-93.

Behn, B. K., Carcello, J. V., Hermanson, D.R., \& Hermanson, R. H. (1997). The determinants of audit client satisfaction among clients of Big 6 firms. Accounting Horizons, 11(1), 724.

Brante, T. (1988). Sociological approaches to the professions, Acta Sociologica, 31(2), 19142.

Broberg, P. (forthcoming). The auditor at work - a study of auditor practice in Big 4 audit firms. PhD Dissertation. Lund University.

Cameran M., Moizer P., \& Pettinicchio A. (2010). Customer satisfaction, corporate image, and service quality in professional services. The Service Industries Journal, 30(3), 421435.

Clow, K. E., Stevens, R. E., McConkey, C. W., \& Loudon, D. L. (2009). Accountants' attitudes toward advertising: a longitudinal study, Journal of Services Marketing, 23(2), 125-132.

Diamantopoulos, A., O’Donohoe, S., \& Lane, J. (1989). Advertising by accountants: An empirical study, Managerial Auditing Journal, 4(1), 3-10.

DiMaggio, P. J., \& Powell, W. W., 1983. The iron cage revisited: Institutional isomorphism and collective rationality in organizational fields, American Sociological Review, 48(2), $147-160$. 
Ellingson, D. A., Hiltner, A. A., Elbert, D. J., \& Gillett, J. (2002). Marketing: Where do accountants stand today? Services Marketing Quarterly, 23(3), 1-15.

FAR SRS Search result 2010. Sökresultat [online] FAR SRS. Available at: <http://www.far.se/portal/page?_pageid=114,340661\&_dad=portal\&_schema=PORTAL> [cited 5 May 2010].

Grönroos, C. (2007). Service Management and Marketing - Customer Management in Service Competition. Chichester, England: John Wiley \& Sons, Ltd.

Gummesson, E. (1979). The marketing of professional services: An organizational dilemma, European Journal of Marketing, 13(5), 308-318.

Hackenbrack K. E. \& Hogan C. E. (2005). Client retention and engagement-level pricing. Auditing: A Journal of Practice \& Theory, 24(1), 7-20.

Hair, J.F., Black, W. C., Babin, B. J., \& Anderson, R. E. (2010). Multivariate Data Analysis: A Global Perspective, 7th edition. Upper Saddle River, N.J.: Pearson Education.

Heischmidt, K., Elfrink, J., \& Mays, B. (2002). Professional accounting services: Types of marketing communications used by CPAs, Services Marketing Quarterly, 23(3), 63-72.

Herda, D. N., \& Lavelle J. J. (2012). Auditor commitment to privately-held clients and its effect on value-added audit service. Forthcoming in Auditing: A Journal of Practice \& Theory.

Hodges, S., \& Young, L. (2009). Unconsciously competent: Academia’s neglect of marketing success in the professions, Journal of Relationship Marketing, 8(1), 36-49.

Hulbert, J. E., \& Lawson, V.S. (1996). The status of advertising in the accounting profession, National public accountant, 41(7), 22-25.

Humphrey, C. G. (2001). Audit research: Looking beyond North America. Critical Perspectives on Accounting, 12(3), 369-376. 
Johansson, S-E., Häckner, E., \& Wallerstedt, E. (2005). Revisorn, revisionsföretaget och framtiden, in: Johansson, Häckner, \& Wallerstedt, Uppdrag revision. Finland: SNS Förlag.

Jönsson, S. (2005). Revisorsrollens nedgång - och fall? in: Johansson, S-E., Häckner, E., \& Wallerstedt, E. Uppdrag revision. Finland: SNS Förlag.

Kotler, P. \& Connor, Jr. R. A. (1977). Marketing professional services, Journal of Marketing, 41(1), 71-76.

Markham, S., Cangelosi, J., \& Carson, M. (2005). Marketing by CPAs: Issues with the American Institute of Certified Public Accountants, Services Marketing Quarterly, 26(3), 71-82.

Mautz, R. K., \& Sharaf, H. A. (1997). The Philosophy of Auditing. Madison, USA: American Accounting Association.

Mintzberg, H. (1983). Structures in Fives: Designing Effective Organizations. New Jersey, USA: Prentice Hall Inc.

Moser, R. H., Colvard, R. G., \& Austin, M. J. (2000). Consumers’ attitudes towards advertising by accounting professionals, Journal of Professional Services, 20(2), 5-18.

O’Donohoe, S., Diamantopoulos, A., \& Petersen, N. (1991). Marketing principles and practice in the accounting profession: a review, European Journal of Marketing, 25(6) $37-54$.

Öhman, P., 2005. Är det viktigare för revisorer att göra saker rätt än att göra rätt saker? in: Johansson, S-E., Häckner, E., \& Wallerstedt, E. Uppdrag revision. Finland: SNS Förlag. Öhman P., Häckner E., \& Sörbom D. (2012). Client satisfaction and usefulness to external stakeholders from an audit client perspective, Managerial Auditing Journal, 27(5), 477499. 
Pallant, J. (2007). SPSS Survival Manual. $3^{\text {rd }}$ edition. Berkshire, England: McGraw Hill Education.

Power, M. (1999). The Audit Society: Rituals of verification. Oxford: Oxford University Press.

Reid, M. (2008). Contemporary marketing in professional services, Journal of Services Marketing. 22(5), 374-384.

Tang, T. L-P., Moser, H. R. \& Austin, M. J. (2002). Attitudes toward advertising by accountants, Services Marketing Quarterly, 23(3), 35-62.

Van Doren, D. C., Smith, L. W., \& Biglin, R. J. (1985). The challenges of professional services marketing, Journal of Consumer Marketing, 2(2), 19-27. 
Table 1 - Auditing and Marketing Activities

\begin{tabular}{cll}
\hline & Activity (as listed in the questionnaire) & Group \\
\hline 1 & Business activities & Auditing \\
2 & Administrative duties & Auditing \\
3 & Education and further training within auditing & Auditing \\
4 & Explain to clients that auditing is important & Marketing \\
5 & Look for prospective clients & Marketing \\
6 & Audit accounting information & Auditing \\
7 & Attend seminars with existing and prospective clients & Marketing \\
8 & Arrange seminars with existing and prospective clients & Marketing \\
9 & Learn about marketing & Marketing \\
10 & Follow-up of new regulations and conducts & Auditing \\
11 & Interact with existing and prospective clients on the Internet & Marketing \\
12 & Perform internal controls for clients & Auditing \\
\hline
\end{tabular}


Table 2 - Correlations

\begin{tabular}{|c|c|c|c|c|c|c|c|c|c|c|c|c|}
\hline & Variable & Mean & Std. Dev. & 1 & 2 & 3 & 4 & 5 & 6 & 7 & 8 & 9 \\
\hline 1 & Sex & 1.33 & .470 & & & & & & & & & \\
\hline 2 & Age & 46.75 & 10.497 & $-.184 * *$ & & & & & & & & \\
\hline 3 & Years as auditor & 14.493 & 9.5734 & $-.235 * *$ & $.887 * *$ & & & & & & & \\
\hline 4 & Attitude A & 5.410 & 1.0787 & $.116^{* *}$ & $-.112 * *$ & -.063 & & & & & & \\
\hline 5 & Attitude M & 4.924 & 1.2988 & .065 & -.051 & -.031 & $.688 * *$ & & & & & \\
\hline 6 & Time A & 4.380 & 0.9633 & $.141^{* *}$ & $-.115^{* *}$ & $-.127 * *$ & $.538 * *$ & $.357 * *$ & & & & \\
\hline 7 & Time M & 3.499 & 1.1620 & .032 & -.023 & -.028 & $.293^{* *}$ & $.596 * *$ & $.544^{* *}$ & & & \\
\hline 8 & Importance A & 5.239 & .8820 & $.190 * *$ & $-.135 * *$ & $-.129 * *$ & $.583^{* *}$ & $.408 * *$ & $.645^{* *}$ & $.358 * *$ & & \\
\hline 9 & Importance M & 4.823 & 1.1981 & $.108 * *$ & $-.113 * *$ & $-.125 * *$ & $.354^{* *}$ & $.626^{* *}$ & $.372 * *$ & $.650 * *$ & $.557 * *$ & \\
\hline 10 & Balance Time & -.8810 & 1.0294 & $-.096 *$ & $.081 *$ & $.088^{*}$ & $-.172 * *$ & $.339 * *$ & $-.321 * *$ & $.619 * *$ & $-.200 * *$ & $.386^{* *}$ \\
\hline
\end{tabular}

** sig.at 0.01

* sig. at 0.05 
Table 3 - Regression Analysis: Attitude Marketing

\begin{tabular}{|c|c|c|c|c|c|c|c|c|c|c|c|}
\hline \multirow[b]{2}{*}{ Variables } & & \multicolumn{2}{|c|}{$\begin{array}{c}\text { Model 1 } \\
\text { With Gender \& Age }\end{array}$} & \multicolumn{2}{|c|}{$\begin{array}{c}\text { Model 2 } \\
\text { With Gender \& Years as } \\
\text { auditor }\end{array}$} & \multicolumn{2}{|c|}{$\begin{array}{c}\text { Model 3 } \\
\text { With Gender, Age, \& } \\
\text { Bureau }\end{array}$} & \multicolumn{2}{|c|}{$\begin{array}{c}\text { Model 4 } \\
\text { With Gender, Years as } \\
\text { auditor, \& Bureau }\end{array}$} & \multicolumn{2}{|c|}{$\begin{array}{c}\text { Model 5 } \\
\text { Without all control } \\
\text { variables }\end{array}$} \\
\hline & & Std. B & Std. Error & Std. B & Std. Error & Std. B & Std. Error & Std. B & Std. Error & Std. B & Std. Error \\
\hline Independent & Attitude & $0.350 * * *$ & 0.028 & $0.348 * * *$ & 0.028 & $0.317 * * *$ & 0.030 & $0.315 * * *$ & 0.030 & $0.339 * * *$ & 0.028 \\
\hline \multirow[t]{14}{*}{ Control } & Gender & $-0.104 * *$ & 0.079 & $-0.101 * *$ & 0.080 & $-0.100 * *$ & 0.079 & $-0.097 * *$ & 0.080 & & \\
\hline & Age & $0.080^{*}$ & 0.004 & & & $0.090 *$ & 0.004 & & & & \\
\hline & Years as auditor & & & $0.075^{*}$ & 0.004 & & & $0.083^{*}$ & 0.004 & & \\
\hline & $\mathrm{BDO}$ & & & & & $-0.067 \dagger$ & 0.181 & $-0.067 \dagger$ & 0.183 & & \\
\hline & Deloitte & & & & & -0.036 & 0.188 & -0.033 & 0.189 & & \\
\hline & Ernst \& Young & & & & & 0.005 & 0.121 & 0.005 & 0.122 & & \\
\hline & Grant Thornton & & & & & $-0.078 *$ & 0.182 & $-0.079 *$ & 0.183 & & \\
\hline & KPMG & & & & & 0.055 & 0.120 & 0.054 & 0.121 & & \\
\hline & PwC & & & & & $-0.103 *$ & 0.104 & $-0.101^{*}$ & 0.104 & & \\
\hline & SET & & & & & -0.042 & 0.243 & -0.042 & 0.244 & & \\
\hline & Constant & $-2.311 * * *$ & 0.256 & $-2.063 * * *$ & 0.192 & 0.168 & 1.229 & 0.435 & 1.242 & $-2.204 * * *$ & 0.142 \\
\hline & $\mathrm{R}^{2}$ & 0.135 & & 0.134 & & 0.159 & & 0.158 & & 0.115 & \\
\hline & Adj. $\mathrm{R}^{2}$ & 0.131 & & 0.130 & & 0.147 & & 0.145 & & 0.114 & \\
\hline & F-Value & $35.741 * * *$ & & $35.122 * * *$ & & $12.851 * * *$ & & $12.604 * * *$ & & $92.218 * * *$ & \\
\hline $\bar{\dagger}$ & $p<.10$ & & & & & & & & & & \\
\hline$*$ & $p<.05$ & & & & & & & & & & \\
\hline$* *$ & $p<.01$ & & & & & & & & & & \\
\hline$* * *$ & $p<0.001$ & & & & & & & & & & \\
\hline
\end{tabular}


Table 4 - Regression Analysis: Importance Marketing

\begin{tabular}{|c|c|c|c|c|c|c|c|c|c|c|c|}
\hline \multirow[b]{2}{*}{ Variables } & & \multicolumn{2}{|c|}{$\begin{array}{c}\text { Model 1 } \\
\text { With Gender \& Age }\end{array}$} & \multicolumn{2}{|c|}{$\begin{array}{c}\text { Model 2 } \\
\text { With Gender \& Years as } \\
\text { auditor }\end{array}$} & \multicolumn{2}{|c|}{$\begin{array}{c}\text { Model 3 } \\
\text { With Gender, Age, \& } \\
\text { Bureau }\end{array}$} & \multicolumn{2}{|c|}{$\begin{array}{c}\text { Model 4 } \\
\text { With Gender, Years as } \\
\text { auditor, \& Bureau }\end{array}$} & \multicolumn{2}{|c|}{$\begin{array}{c}\text { Model 5 } \\
\text { Without all control } \\
\text { variables }\end{array}$} \\
\hline & & Std. B & Std. Error & Std. B & Std. Error & Std. B & Std. Error & Std. B & Std. Error & Std. B & Std. Error \\
\hline Independent & Importance & $0.411^{* * *}$ & 0.030 & $0.412 * * *$ & 0.030 & $0.408^{* * *}$ & 0.032 & $0.409 * * *$ & 0.032 & $0.386^{* * *}$ & 0.030 \\
\hline \multirow[t]{14}{*}{ Control } & Gender & $-0.121 * * *$ & 0.077 & $-0.114 * *$ & 0.078 & $-0.119 * * *$ & 0.076 & $-0.113 * *$ & 0.078 & & \\
\hline & Age & $0.105 * *$ & 0.003 & & & $0.113 * *$ & 0.003 & & & & \\
\hline & Years as auditor & & & $0.112 * *$ & 0.004 & & & $0.117 * * *$ & 0.004 & & \\
\hline & BDO & & & & & $-0.064 \dagger$ & 0.174 & $-0.065 \dagger$ & 0.175 & & \\
\hline & Deloitte & & & & & -0.044 & 0.181 & -0.041 & 0.181 & & \\
\hline & Ernst \& Young & & & & & 0.039 & 0.118 & 0.037 & 0.119 & & \\
\hline & Grant Thornton & & & & & $-0.096 * *$ & 0.175 & $-0.098 * *$ & 0.176 & & \\
\hline & KPMG & & & & & $0.095^{*}$ & 0.117 & $0.094 *$ & 0.118 & & \\
\hline & PwC & & & & & $-0.083 *$ & 0.099 & $-0.081 *$ & 0.100 & & \\
\hline & SET & & & & & -0.012 & 0.236 & -0.013 & 0.237 & & \\
\hline & Constant & $-2.714 * * *$ & 0.258 & $-2.433 * * *$ & 0.196 & -1.015 & 1.190 & -0.688 & 1.198 & $-2.480 * * *$ & 0.148 \\
\hline & $\mathrm{R}^{2}$ & 0.178 & & 0.180 & & 0.214 & & 0.214 & & 0.149 & \\
\hline & Adj. $\mathrm{R}^{2}$ & 0.175 & & 0.176 & & 0.202 & & 0.203 & & 0.148 & \\
\hline & F-Value & $49.755^{* * *}$ & & $49.667 * * *$ & & 18.502 & & $18.374 * * *$ & & $124.144 * * *$ & \\
\hline $\bar{\dagger}$ & $p<.10$ & & & & & & & & & & \\
\hline$*$ & $p<.05$ & & & & & & & & & & \\
\hline$* *$ & $p<.01$ & & & & & & & & & & \\
\hline$* * *$ & $p<0.001$ & & & & & & & & & & \\
\hline
\end{tabular}


Table 5 - Attitude Pattern Matrix

\begin{tabular}{|c|c|c|c|c|c|}
\hline & & Original & & Component & \\
\hline & & Group & 1. Marketing & 2. Auditing & 3. Other \\
\hline 2.8 & Arrange seminars & $\mathrm{M}$ & .907 & .006 & -.045 \\
\hline 2.5 & Look for prospective clients & M & .873 & .002 & -.079 \\
\hline 2.9 & Learn about marketing & M & .759 & -.122 & .123 \\
\hline 2.7 & Attend seminars & M & .750 & .219 & -.131 \\
\hline 2.1 & Firm activities & A & .568 & .058 & .418 \\
\hline 2.4 & Explain auditing is important & M & .384 & .332 & .207 \\
\hline 2.10 & Follow-up new regulations & A & -.051 & .859 & .030 \\
\hline 2.12 & Perform internal control for clients & A & .020 & .801 & -.139 \\
\hline 2.6 & Audit accounting information & A & .174 & .690 & -.233 \\
\hline 2.3 & Education within auditing & A & .097 & .610 & .237 \\
\hline 2.11 & Interact online with clients & M & -.074 & .560 & .182 \\
\hline 2.2 & Administration & A & .048 & .058 & .871 \\
\hline
\end{tabular}


Table 6 - Importance Pattern Matrix

\begin{tabular}{llcccc}
\hline & & Original & & Component & \\
& & Group & 1. Marketing & 2. Auditing & 3. Other \\
\hline 4.8 & Arrange seminars & $\mathrm{M}$ & $\mathbf{. 8 7 6}$ & -.010 & -.079 \\
4.5 & Look for prospective clients & $\mathrm{M}$ &. $\mathbf{8 4 5}$ & .059 & -.155 \\
4.7 & Attend seminars & $\mathrm{M}$ & .796 & .171 & -.149 \\
4.9 & Learn about marketing & $\mathrm{M}$ & $\mathbf{. 6 7 2}$ & -.105 & .248 \\
4.1 & Firm activities & $\mathrm{A}$ & $\mathbf{. 6 1 9}$ & -.100 & .317 \\
4.4 & Explain auditing is important & $\mathrm{M}$ &. $\mathbf{4 3 2}$ & .193 & .307 \\
4.10 & Follow-up new regulations & $\mathrm{A}$ & -.092 &. $\mathbf{8 5 4}$ & .131 \\
4.3 & Education within auditing & $\mathrm{A}$ & -.030 & .778 & .161 \\
4.12 & Perform internal control for clients & $\mathrm{A}$ & .050 & .714 & -.044 \\
4.6 & Audit accounting information & $\mathrm{A}$ & .222 &. $\mathbf{6 8 3}$ & -.286 \\
4.2 & Administration & $\mathrm{A}$ & .106 & -.050 &. $\mathbf{7 4 9}$ \\
4.11 & Interact online with clients & $\mathrm{M}$ & -.027 & .365 & .546 \\
\hline
\end{tabular}


Table 7 - Balance Time Pattern Matrix

\begin{tabular}{llccc}
\hline & Original & & Component \\
& & Group & 1. Marketing & 2. Auditing \\
\hline 3.8 & Arrange seminars & $\mathrm{M}$ & $\mathbf{. 8 8 4}$ & -.073 \\
3.5 & Look for prospective clients & $\mathrm{M}$ & $\mathbf{. 8 2 0}$ & -.043 \\
$3.7 \quad$ Attend seminars & $\mathrm{M}$ &. $\mathbf{7 8 3}$ & .059 \\
3.9 & Learn about marketing & $\mathrm{M}$ & .744 & -.067 \\
3.1 & Firm activities & $\mathrm{A}$ & .724 & .001 \\
3.4 & Explain auditing is important & $\mathrm{M}$ & .592 & .178 \\
3.12 Perform internal control for clients & $\mathrm{A}$ & -.085 & $\mathbf{. 7 9 5}$ \\
3.10 & Follow-up new regulations & $\mathrm{A}$ & .029 & $\mathbf{. 7 8 2}$ \\
3.6 & Audit accounting information & $\mathrm{A}$ & -.057 & $\mathbf{. 6 7 8}$ \\
3.3 & Education within auditing & $\mathrm{A}$ & .248 & $\mathbf{. 5 6 6}$ \\
\hline
\end{tabular}




\section{Table 8 - Means}

\begin{tabular}{|c|c|c|c|c|c|c|}
\hline \multirow[b]{2}{*}{ Activity } & \multicolumn{2}{|c|}{ Attitude } & \multicolumn{2}{|c|}{ Time } & \multicolumn{2}{|c|}{ Importance } \\
\hline & Mean & $\begin{array}{l}\text { Std. } \\
\text { dev. }\end{array}$ & Mean & $\begin{array}{l}\text { Std. } \\
\text { dev. }\end{array}$ & Mean & $\begin{array}{l}\text { Std. } \\
\text { dev. }\end{array}$ \\
\hline 1. Firm activities & 4.89 & 1.678 & 3.49 & 1.457 & 4.26 & 1.593 \\
\hline 2. Administration & 4.26 & 1.653 & 3.63 & 1.505 & 3.49 & 1.532 \\
\hline 3. Education within auditing & 5.81 & 1.339 & 4.19 & 1.305 & 6.13 & 1.093 \\
\hline 4. Explain auditing is important & 5.29 & 1.488 & 3.57 & 1.556 & 5.16 & 1.553 \\
\hline 5. Look for prospective clients & 5.04 & 1.807 & 3.49 & 1.676 & 5.11 & 1.698 \\
\hline 6. Audit accounting information & 6.08 & 1.371 & 5.62 & 1.532 & 6.01 & 1.330 \\
\hline 7. Attend seminars & 5.57 & 1.668 & 3.97 & 1.706 & 5.37 & 1.589 \\
\hline 8. Arrange seminars & 4.74 & 1.956 & 3.10 & 1.672 & 4.61 & 1.790 \\
\hline 9. Learn about marketing & 3.22 & 1.792 & 2.01 & 1.295 & 3.44 & 1.699 \\
\hline 10. Follow-up new regulations & 6.07 & 1.162 & 4.98 & 1.347 & 6.18 & 1.049 \\
\hline 11. Interact online with clients & 5.91 & 1.322 & 5.10 & 1.576 & 5.51 & 1.406 \\
\hline 12. Perform internal control for clients & 5.64 & 1.541 & 4.69 & 1.586 & 5.54 & 1.419 \\
\hline
\end{tabular}


Appendix 1

1. Background

\begin{tabular}{|c|c|c|c|c|}
\hline $\begin{array}{l}1.1 \\
1.2\end{array}$ & $\begin{array}{l}\text { Gender } \\
\text { Age }\end{array}$ & $\square$ Male & $\square$ Female & \\
\hline 1.3 & Number of years & & & \\
\hline 1.4 & Bureau affiliation & $\begin{array}{l}\text { BDO } \\
\square \text { Grant Thornton }\end{array}$ & $\begin{array}{l}\square \text { Deloitte } \\
\square \text { KPMG }\end{array}$ & $\begin{array}{l}\square \text { Ernst \& Young } \\
\square \text { Pricewaterhous } \\
\text { eCoopers }\end{array}$ \\
\hline
\end{tabular}

2. How would you agree to the following activities being part of your role as a professional auditor?

Mark your opinion on the 7-point scale between "Totally disagree" and "Totally agree".

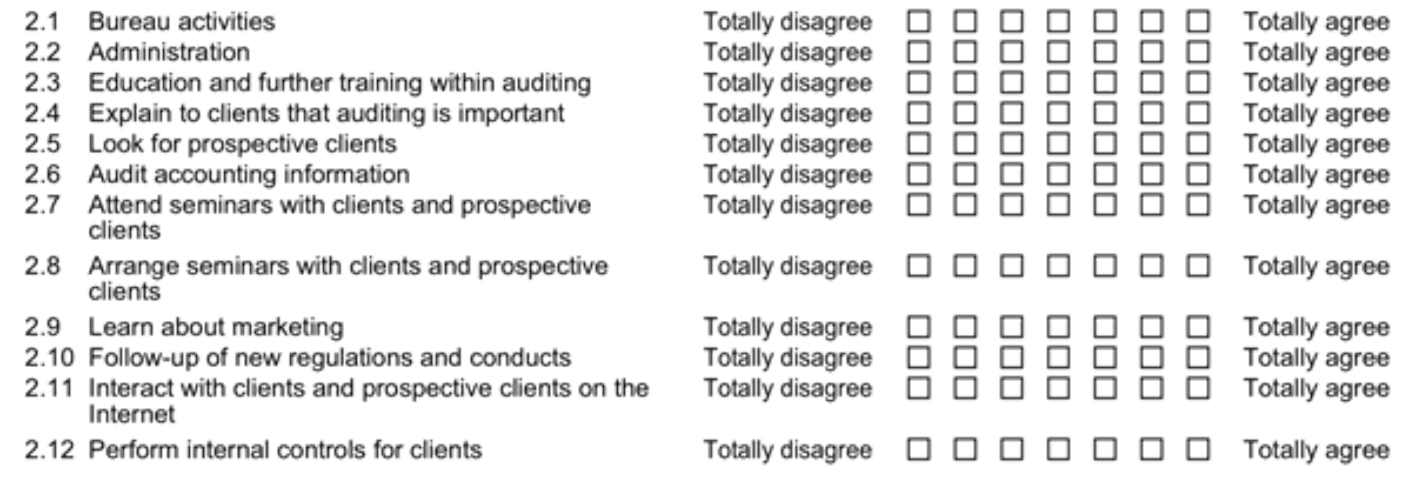

3. How much time on average do you as a professional auditor spend on the following activities?

Mark your opinion on the 7-point scale between "No time at all" and "A lot of time".

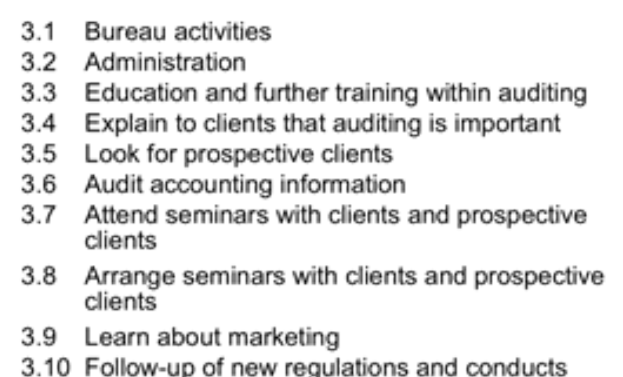

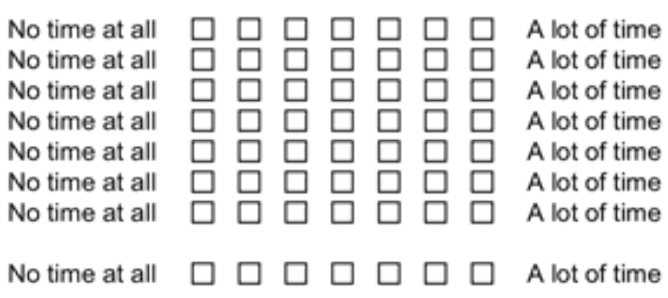

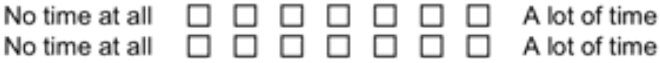




\section{How important do you as a professional auditor think the following activities are?}

Mark your opinion on the 7-point scale between "Not at all important" and "Very important".

4.1 Bureau activities

4.2 Administration

4.3 Education and further training within auditing

4.4 Explain to clients that auditing is important

4.5 Look for prospective clients

4.6 Audit accounting information

4.7 Attend seminars with clients and prospective clients 4.8 Arrange seminars with clients and prospective
clients

4.9 Learn about marketing

4.10 Follow-up of new regulations and conducts 4.11 Interact with clients and prospective clients on the
Internet

4.12 Perform internal controls for clients

\begin{abstract}
Not at all $\quad \square \square \square \square \square \square$ Very important
important

Not at all $\square \square \square \square \square \square \square$ Very important

important

important

Not at all $\quad \square \square \square \square \square \square$ Very important

important

Not at all $\square \square \square \square \square \square \square$ Very important

importan

Not at all $\quad \square \quad \square \square \square \square$ Very important

important

Notat all $\quad \square \quad \square \quad \square \quad \square$ Very important

important

Not at all $\quad \square \square \square \square \square \square$ Very important

important

Not at all $\quad \square \quad \square \quad \square=0$

Not at all $\square \square \square \square \square \square \square$ Very important

important

Not at all $\square \square \square \square \square \square \square$ Very important

Not at all
important $\square \square \square \square \square \square \quad$ Very important

important
\end{abstract}

Thank you! 